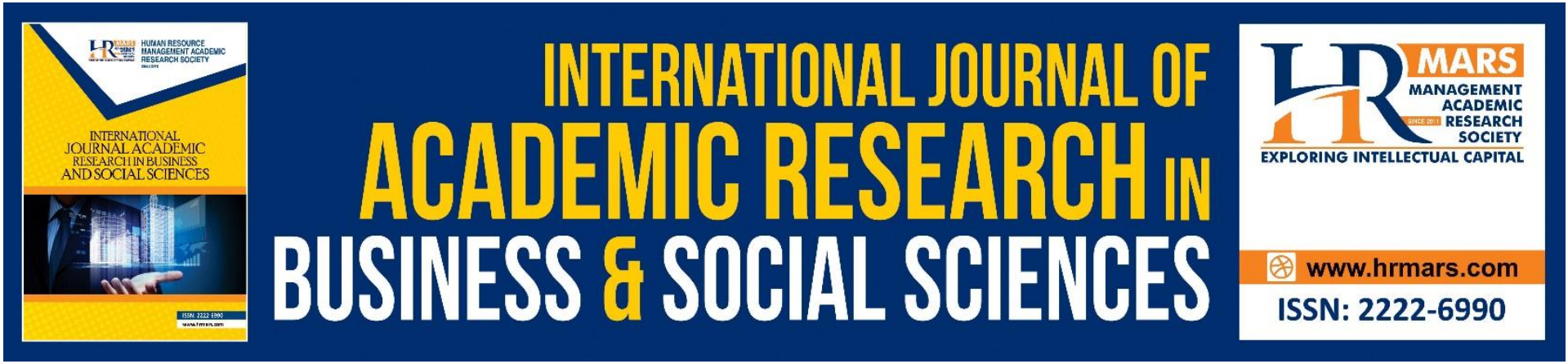

\title{
A Framework to Explore Customer Experience on First-Store Design Concept in China
}

Cuiyu Xi, Muhammad Zaffwan Idris

To Link this Article: http://dx.doi.org/10.6007/IJARBSS/v11-i1/8537

DOI:10.6007/IJARBSS/v11-i1/8537

Received: 02 December 2020, Revised: 30 December 2020, Accepted: 14 January 2021

Published Online: 26 January 2021

In-Text Citation: (Xi, \& Idris, 2021)

To Cite this Article: Xi, C., \& Idris, M. Z. (2021). A Framework to Explore Customer Experience on First-Store Design Concept in China. International Journal of Academic Research in Business and Social Sciences, 11(1), 475-482.

\section{Copyright: (C) 2021 The Author(s)}

Published by Human Resource Management Academic Research Society (www.hrmars.com)

This article is published under the Creative Commons Attribution (CC BY 4.0) license. Anyone may reproduce, distribute, translate and create derivative works of this article (for both commercial and non-commercial purposes), subject to full attribution to the original publication and authors. The full terms of this license may be seen at: http://creativecommons.org/licences/by/4.0/legalcode

Vol. 11, No. 1, 2021, Pg. 475 - 482

Full Terms \& Conditions of access and use can be found at http://hrmars.com/index.php/pages/detail/publication-ethics 


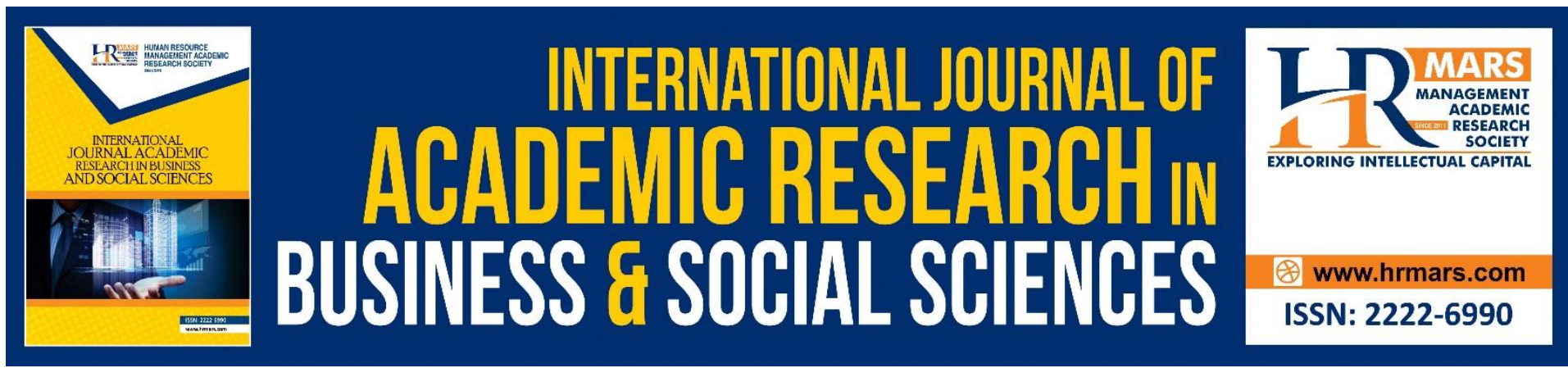

\title{
A Framework to Explore Customer Experience on First-Store Design Concept in China
}

\author{
Cuiyu Xi, Muhammad Zaffwan Idris \\ Faculty of Art, Computing \& Creative Industry, Universiti Pendidikan Sultan Idris, Tanjong \\ Malim, Perak, 35900, Malaysia \\ Email: zaffwan@fskik.upsi.edu.my
}

\begin{abstract}
Driven by big data, the development of new technology and the enhancement of customer experience $(C X)$, the first-store transformed the retail industry. Based on customer-centric approach and driven by S-O-R model, this paper proposed a new framework to amplify the quality of CX. Furthermore, this study is proposing the adaptation from service design tools including personas and customer journey map. Thus, data are collected from the customer visit at first-store by dividing it into three stages: pre-visit, during-visit, and post-visit. Consumer personas are generated according to the market segmentation theory, which was proposed as a part of the framework proposed in this paper.
\end{abstract}

Keywords: Customer Experience, First-Store, Service Design, Persona, Brand Personality

\section{Introduction}

Alibaba, China's largest online shopping company, has come up with a new concept for retail, a new industry form that combines online and offline channels and integrates with new technologies such as big data. The first-store, as a representative sample of new retail, has seen rapid development in China's first-tier cities in 2019. The first-store is designed to improve customer experience, thereby increasing customer satisfaction, loyalty, and marketing. Managers and designers should be aware that they need to shift the traditional design thinking model from designer-centric to client-centric.

\section{First-Stores Design Concept}

The Definition of First-Store

The term "first-store" first appeared in news reports of international chain brands entering the Chinese market, meaning the first-store to appear in a geographic area. In 2017-2019, in the commercial data released by Chinese commercial institutions, the term "first store" was formally used, and systematic and comprehensive statistics were performed on it (Ruiyide, 2019b). The first-store is different from the traditional brick-and-mortar store and is the most representative sample of new retail (IT Beacon, 2019).

To some extent, the concept of first-store reflects the evolution of the world's first-store, Asia's first-store, China's first-store, the region's first-store, the new species store, the concept store, the experience store, the custom store, and the flagship store (Wen, 2019). 
The first-store economy refers to an economic form in which a region uses unique resource advantages to attract domestic and foreign brands to open stores for the first time in the region, to achieve optimal coupling between brand value and regional resources, and thus have a positive impact on the regional economic development (Ruiyide, 2019b).

Features of First-Store

(1) First-store and city: First-store helps cities achieve differentiated development. (2) Firststore and shopping center: First-store helps the shopping center to break through the traffic and differentiation dilemma, and glimpse future business trends. The first-store has absolute advantages in fans' influence, creating communication topics and accumulating traffic. (3) First-store and social media: Social media not only reduces the cost of market education before the brand enters the regional market, but also amplifies the marketing value of firststore brand through user-generated communication content, and extends to shopping centers and cities (Ruiyide, 2019a).

\section{Customer Experience (CX)}

Homburg, Jozić, and Kuehnl (2017) give a comprehensive and novel definition of CX: "Customer experience is the evolvement of a person's sensorial, affective, cognitive, relational, and behavioral responses to a firm or brand by living through a journey of touchpoints and continually judging this journey against response thresholds of co-occurring experiences in a person's related environment." CX is a multidimensional frame and it means all the touchpoints when the customer safari in the shopping journey with a brand. The target of $C X$ is to provide optional experience for customers at all touchpoints. According to Patterson (2018), touchpoint means any interaction that might alter the way that customer feels with brand, service, and product.

$C X$ and user experience (UX) do have different meanings. UX is focused on product-specific, while $C X$ is a bigger concept than it. CX includes all the experiences when the user (or customer) interacts with the brand. To some extent, UX is also a stage of the CX.

\section{CX on Store}

First-store and new retail are new things that have only appeared in 2019. At present, there is no research on customer experience for new retail or first-store. But there are some research findings of the atmosphere and experience of traditional brick and mortar stores. The experience research of physical stores is mainly applied in the field of visual marketing, which can not only help improve the competitiveness of brands but also improve customer satisfaction.

\section{The Model of S-O-R}

S-O-R model is an important theory of environmental psychology. It depicted how people respond to stimuli in the environment in three steps: Stimulus (S), Organism (O), and Response (R). Environmental stimuli lead to customer's responses (avoidance or approach) which were generated by customer's sensory organs of different cues in the environment (Robert \& John, 1982).

\section{Atmospheric Effect in Retail Store}

Based on the S-O-R model, Turley and Milliman provided a model of the effect of store atmosphere on shopping behavior (2000). Elements such as exterior, general interior, store 
layout, interior displays and human variables are regarded as atmospheric stimuli. The model gave the responses of employees and customers as organisms respectively.

With the introduction of "experience economy" (Pine \& Gilmore, 2011), brands began to focus on providing customers with hedonistic shopping experience. Ballantine, Jack, and Parsons found that store atmospheric cues influenced hedonistic experiences. (2010). They pointed out that two cues categories affect customers' hedonic experience. Attractive stimuli attracted attention, exciting the customer, and lead to attitude doings, and it consists of lighting, sound, space, color, layout, product display features, and design features. While another cue facilitating stimuli that were needed to facilitate product interaction, and it consists of comfort features, crowding, lighting, product display features, and employees.

Cachero-Martínez and Vázquez-Casielles (2017) have reported the conceptual model of CX dimensions in physical store. They presented a detailed interpretation of relationships between customer experience, customer satisfaction, and shopping experience value perception (hedonic and utilitarian). This research also has highlighted four experience dimensions: sensory experience, intellectual experience, social experience, and pragmatic experience (Cachero-Martínez \& Vázquez-Casielles, 2017).

The environment-user relationships in service framework (Bitner, 1992) presented that retail store environmental dimensions are sensed by both employees and consumers and lead to emotional, cognitive and physiological reactions, including behavior avoidance and approach. The five senses (visual, auditory, tactile, taste, and scent) are the most critical factors of the physical store environment in the experience-centric services (Zomerdijk \& Voss, 2010).

According to Nan and Liang (2019), a theoretical framework was designed as the fundamental exhibition factors presented communicative conjunction between humans and exhibitions. They described human exhibition interaction and explored 59 factors of exhibition design, 18 factors of user experience and 14 reactive behavior. The framework is based on the interaction between humans and exhibitions. The systematic design factors of retail atmosphere obtained through the analysis of grounded theory will provide support for this research, but this framework does not involve customer consumption.

A review of the literature reveals that the research on store atmosphere and experience mainly focuses on the effect of environmental variables on individuals and their subsequent behaviors. Most of the research is based on the S-O-R model of environmental psychology. These findings can help designers evoke customer-specific emotions and behavioral responses through the design of the physical environment. Therefore, how to manage and handle atmospheric variables becomes an important link for creating an unforgettable service experience. The research gap is that the customer experience is limited to the inside of a physical store and does not consider the pre-purchase and post-purchase stages of the customer.

\section{Using Service Design to Establish the Customer-centric First-store Concept}

The service design approach emphasizes the importance of the experience-centric (Zomerdijk \& Voss, 2010). It involves the disciplines of marketing, organizational structure, aesthetic design, human resources, operations, management and so on, is a holistic service system (Teixeira et al., 2012). The essence of service design is to probe the relationship among humans, products, behavior, environment, and society from a systematic perspective by taking "touchpoints" in the service system as a clue, to create optional experience and value for customers. 


\section{Persona and Personas Generating Procedure}

Persona in service design help consumers contributes their knowledge and skills to create optional dimensions of value and experience. Persona is the abstraction of a group of truthful customers who share universal identities and needs (Pruitt \& Adlin, 2010). It has been widely used in the field of customer experience research. In this study, customer personas were select from participants. The selection of process is based on the market segmentation theory: geographic (Wedel \& Kamakura, 2012), demographic (Orangi \& Kimemia, 2018), psychographic (Weinstein, 1994; Goyat, 2011). First of all, from the perspective of geographical division, this study is confined to Beijing, China. Secondly, the demographic segmentation scope was defined as Gen Y group. Finally, this study will select personas with five different brand personalities through the questionnaire. According to Aaker's (1997) brand personality theory, this study generates five personas from the target customer groups: sincerity, excitement, competence, sophistication and ruggedness (Figure 1).

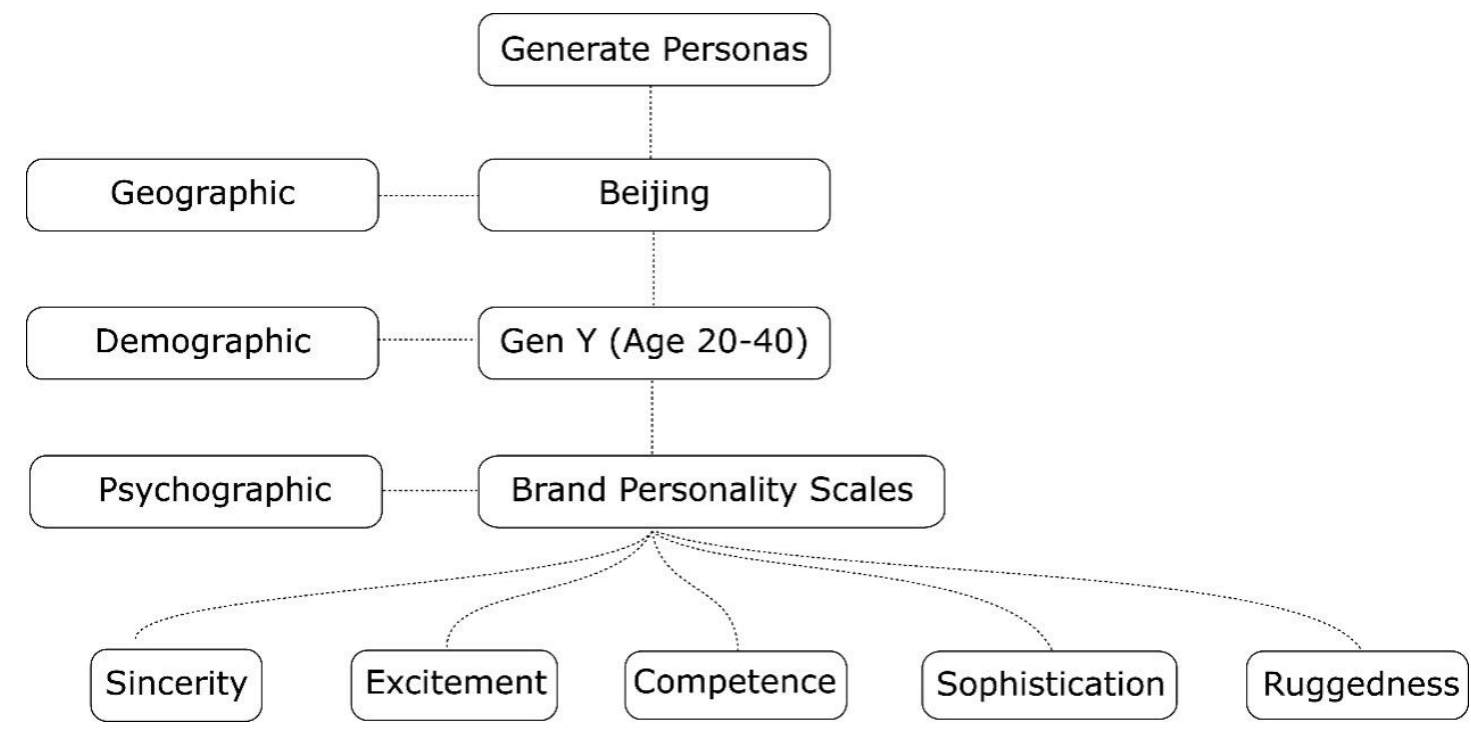

Figure 1: Customer Persona Generating Procedure

\section{Customer Journey Map (CJM) on First-store}

According to Kalliala (2019), the customer journey map covers all stages of customer interaction with the brand, not only products, online and offline experiences, but also services. Prior research (Neslin et al., 2006; Puccinelli et al., 2009; Lemon \& Verhoef, 2016b) conceptualizes customer experiences in three stages: prepurchase, purchase, and postpurchase. Thus, first-store experiences should include the stage of obtaining information through online resources pre-visit and the process of posting comments on social media postvisit, thus forming a complete closed-loop of the customer journey. In this study, the researcher focuses on the more comprehensive touchpoints of customers on the first-store experience, including online platform (pre-visit), physical store (during-visit), and postpurchase section, as well as online comments (post-visit).

\section{A Framework to Exploring CX on First-Store}

As shown in figure 2 below: this research mainly uses the service design approach to explore the problem. At first, it is the use of persona tools. The generation of persona is based on market segmentation theory and Aaker's (1997) brand personality theory. Second, the research process covers a complete first-store customer journey map, and the touchpoints of 
experience will be conducted in three different stages: pre-visit, during-visit and post-visit. Thirdly, this study will use three service design tools to collect data: service safari (Stickdorn, Hormess, Lawrence, \& Schneider, 2018), mobile ethnography (Segelström \& Holmlid, 2012), and context interview (Reason, Løvlie, \& Flu, 2015). Five personas with different brand personalities, selected from the participants, will receive a sum of money and be asked to complete a shopping task at the designated first-store. During the task, they need to use their smartphones to record some videos, photos, or sounds. At the same time, the researchers will follow them and conduct contextual interviews on-site at three different customer journey map phases. The list of questions in the interview outline is a semi-structured interview to obtain the corresponding persona visit data.

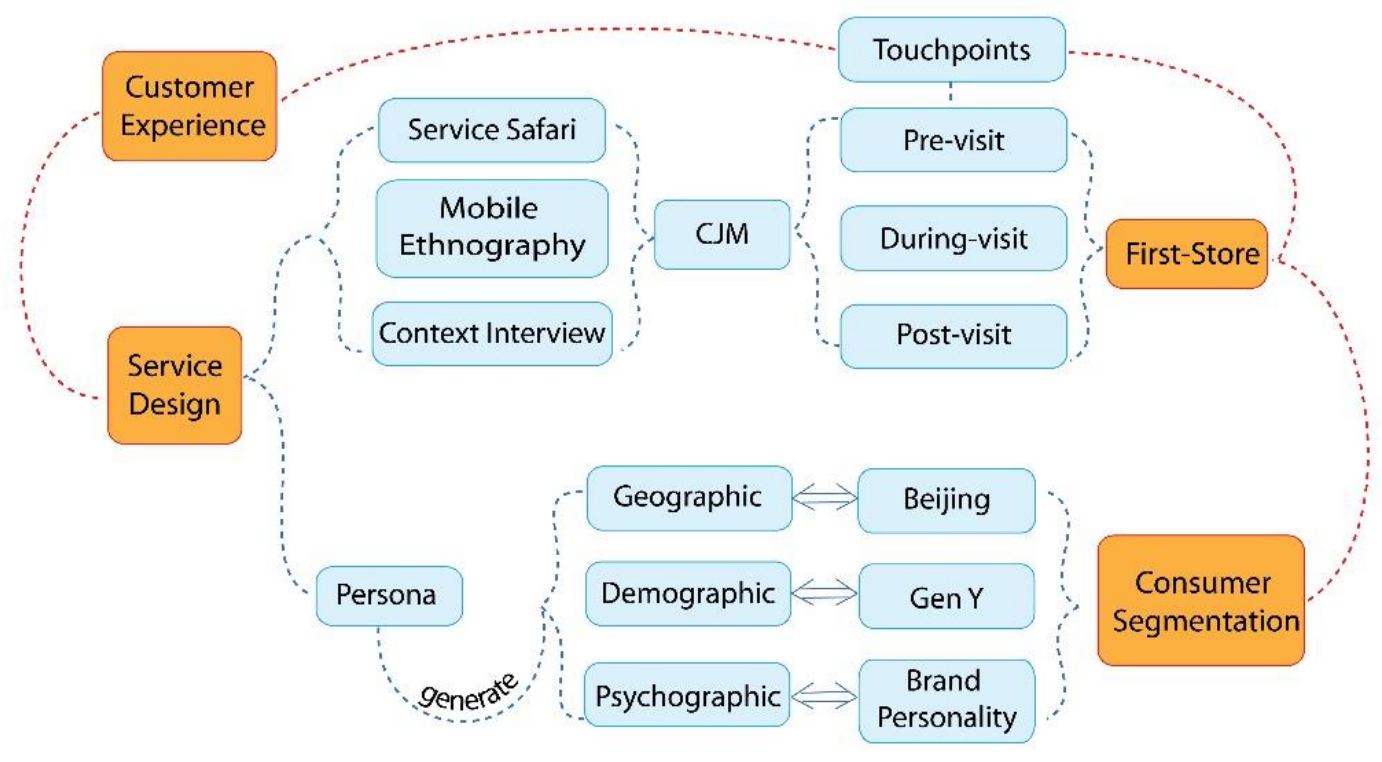

Figure 2: A Framework to Explore CX on First-Store

\section{Conclusion}

In a word, this paper introduced the concept and features of first-store, as well as proposes a new framework to explore the CX of generation $Y$ in Beijing, China on first-store service. In the first half of the paper, the authors found out the existing theories in the field of store design and CX through literature review and pointed out the research gap. In 2020, in the context of COVID-19, the integration of physical stores and online channels in the concept of first-store becomes more important. This framework used service design methodology to help establish a new first-store service design concept. The purpose of this study is to better understand the experience needs of the target consumer groups of first-store.

The theoretical contribution of this study is to apply the service design approach to first-store design. That is to put forward a new customer experience-centered theoretical perspective to explore the construction and development of first-store. Through literature review, this study proposes a feasible theoretical framework and approach to explore the CX of first-store. As first-store is a new concept, the findings of this study will provide guidelines for first-store concept establishment. 


\section{References}

Aaker, J. L. (1997). Dimensions of brand personality. Journal of Marketing Research, 34(3), 347-356. https://doi.org/10.2307/3151897

Ballantine, P. W., Jack, R., \& Parsons, A. G. (2010). Atmospheric cues and their effect on the hedonic retail experience. International Journal of Retail and Distribution Management, 38(8), 641-653. https://doi.org/10.1108/09590551011057453

Bitner, M. J. (1992). Using Background Music to Affect the Behaviour of Supermarket Shoppers. Journal of Marketing, 56(2), 57. https://doi.org/10.2307/1252042

Cachero-Martinez, S., \& Vazquez-Casielles, R. (2017). Living positive experiences in store: how it influences shopping experience value and satisfaction? Journal of Business Economics and Management, 18(3), 537-553. https://doi.org/10.3846/16111699.2017.1292311

Goyat, S. (2011). The basis of market segmentation: a critical review of literature. European Journal of Business and Management, 3(9), 45-54.

Homburg, C., Jozic, D., \& Kuehnl, C. (2017). Customer experience management: toward implementing an evolving marketing concept. Journal of the Academy of Marketing Science, 45(3), 377-401. https://doi.org/10.1007/s11747-015-0460-7

IT Beacon. (2019). Why is the "first-store economy" the latest practice sample of new retail? Retrieved from http://www.sohu.com/a/310681832_351509

Kalliala, M. (2019). Customer Journey Mapping: Skateboard hardware purchases, (May).

Lemon, K. N., \& Verhoef, P. C. (2016). Understanding customer experience throughout the customer journey. Journal of Marketing, 80(6), 69-96. https://doi.org/10.1509/jm.15.0420

Nan, W., \& Liang, X. (2019). Human-exhibition interaction (HEI) in designing exhibitions: A systematic literature review. International Journal of Hospitality Management, 77(July), 292-302. https://doi.org/10.1016/j.ijhm.2018.07.009

Neslin, S. A., Grewal, D., Leghorn, R., Shankar, V., Teerling, M. L., Thomas, J. S., \& Verhoef, P. C. (2006). Challenges and opportunities in multichannel customer management. Journal of Service Research, 9(2), 95-112. https://doi.org/10.1177/1094670506293559

Orangi, A. K., \& Kimemia, M. (2018). Determinant of Age as a Demographic Segmentation Practice on Consumer Choice of Ready to Wear Clothes in Kenya.

Patterson, L. (2018). Customer Touchpoints - The Point of Interaction Between Brands, Businesses, Products and Customers. Retrieved from https://www.interactiondesign.org/literature

Pine, B. J., \& Gilmore, J. H. (2011). The experience economy. Harvard Business Press.

Pruitt, J., \& Adlin, T. (2010). The persona lifecycle: keeping people in mind throughout product design. Elsevier.

Puccinelli, N. M., Goodstein, R. C., Grewal, D., Price, R., Raghubir, P., \& Stewart, D. (2009). Customer Experience Management in Retailing: Understanding the Buying Process. Journal of Retailing, 85(1), 15-30. https://doi.org/10.1016/j.jretai.2008.11.003

Reason, B., Løvlie, L., \& Flu, M. (2015). Service design for business. Wiley Online Library.

Robert, D., \& John, R. (1982). Store atmosphere: an environmental psychology approach. Journal of Retailing, 58(1), 34-57.

Ruiyide. (2019a). Beijing first-store data published in the first half of 2019. Retrieved from https://mp.weixin.qq.com/s

Ruiyide. (2019b). China's First-Store Economy Research Report. Retrieved from https://m.huxiu.com/article/300363.html 
Segelstrom, F., \& Holmlid, S. (2012). One Case, Three Ethnographic Styles: Exploring different ethnographic approaches to the same broad brief. Ethnographic Praxis in Industry Conference Proceedings, 2012(1), 48-62. https://doi.org/10.1111/j.15598918.2012.00007.x

Stickdorn, M., Hormess, M. E., Lawrence, A., \& Schneider, J. (2018). This is service design doing: Applying service design thinking in the real world. "O'Reilly Media, Inc."

Teixeira, J., Patricio, L., Nunes, N. J., Nóbrega, L., Fisk, R. P., \& Constantine, L. (2012). Customer experience modeling: From customer experience to service design. Journal of Service Management, 23(3), 362-376. https://doi.org/10.1108/09564231211248453

Turley, L. W., \& Milliman, R. E. (2000). Atmospheric effects on shopping behavior: A review of the experimental evidence. Journal of Business Research, 49(2), 193-211. https://doi.org/10.1016/S0148-2963(99)00010-7

Wedel, M., \& Kamakura, W. A. (2012). Market segmentation: Conceptual and methodological foundations (Vol. 8). Springer Science \& Business Media.

Weinstein, A. T. (1994). Market Segmentation: Using Demographics, Psychographics and Other Niche Marketing Techniques to Predict Customer Behavior. Probus Publishing Co.

Wen, C. (2019). First-store economy, new city competition. Industry City, 80-81.

Zomerdijk, L. G., \& Voss, C. A. (2010). Service desing for experience-centric services. Journal of Service Research, 13(1), 67-82. https://doi.org/10.1177/1094670509351960 